\title{
Politicians' Luck of the Draw: Evidence from the Spanish Christmas Lottery
}

\section{Manuel Bagues}

Aalto University and Institute for the Study of Labor (IZA)

\section{Berta Esteve-Volart}

York University

\begin{abstract}
Incumbent politicians tend to receive more votes when economic conditions are good. In this paper we explore the source of this correlation, exploiting the exceptional evidence provided by the Spanish Christmas Lottery. Because winning tickets are typically sold by one lottery outlet, winners tend to be geographically clustered. This allows us to study the impact of exogenous good economic conditions on voting behavior. We find that incumbents receive significantly more votes in winning provinces. The evidence is consistent with a temporary increase in happiness making voters more lenient toward the incumbent, or with a stronger preference for the status quo.
\end{abstract}

\section{Introduction}

There is substantial evidence showing a robust correlation between economic outcomes and the reelection of incumbent politicians in elec-

We are grateful for the useful comments and suggestions provided by George Akerlof, Tim Besley, Gustavo Bobonis, Stéphane Bonhomme, Antonio Cabrales, Guillermo Caruana, Abel Fernández, Nicole Fortin, Javier Gardeazábal, Roberto Garvía, Alex Haslam, John Helliwell, Andrea Ichino, Nic Morgan, Torsten Persson, Aloysius Siow, Ernesto Villanueva, Natalia Zinovyeva, as well as the editor and three anonymous referees, whose suggestions greatly improved the paper. We also thank seminar participants at the Helsinki Center of Economic Research, Centro de Estudios Monetarios y Financieros, Universita' di Bologna, University of Toronto, Institut d'Economia de Barcelona, International Meeting on Exper-

Electronically published August 31, 2016

[ Journal of Political Economy, 2016, vol. 124, no. 5]

(c) 2016 by The University of Chicago. All rights reserved. 0022-3808/2016/12405-0002\$10.00 
tions. ${ }^{1}$ While the existence of economic voting seems to be a stylized fact, its causes are not yet well understood. In a context of asymmetric information, voters may interpret economic conditions as a signal of an incumbent's ability or effort and thus apply a simple retrospective voting rule (Nordhaus 1989). Economic voting may also be partly due to voters' systematic attribution errors. There is experimental evidence in social psychology finding that subjects aiming to assess competence systematically fail to take sufficient account of background or environmental factors (Ross and Nisbett 1991).

It is difficult to disentangle empirically why economic outcomes affect voting behavior. There are at least two challenges that are common to most empirical studies tackling this issue. The first problem is how to identify variations in economic conditions that are independent from incumbents' actions. $^{2}$

Second, even in the case of seemingly exogenous events in which incumbents may not have direct control over the event itself, the incumbents may be plausibly held responsible by voters for either (lack of) preparation or response. ${ }^{3}$ If voters hold positive priors about the incumbent, the additional information will tend, on average, to decrease support for the incumbent (Asworth and Bueno de Mesquita 2014).

In this paper, we try to overcome these issues by exploiting the exceptional evidence provided by a unique randomized natural experiment: the Spanish Christmas Lottery. This lottery, held every Christmas, offers sev-

imental and Behavioral Economics, Consejo Superior de Investigaciones Científicas, Hebrew University, Universidad Carlos III de Madrid, BI Norwegian Business School, Canadian Institute for Advanced Research Social Interactions, Identity, and Well-Being Program fall 2012 meetings, Queen Mary, University of Edinburgh, University of Bristol, Allied Social Science Associations meetings, University of Essex, University of Warwick, University of Waterloo, and Queen's University. We are also particularly grateful to Alberto Lafuente and Sistemas Técnicos de Loterías for granting us access to the lottery data. Celia Martín provided excellent research assistance. Any remaining errors are our own. We acknowledge the financial support of the Social Sciences and Humanities Research Council of Canada and the Spanish Ministry of Science and Technology (research grants ECO2008-06395C05-05 and ECO2008-01116). Data are provided as supplementary material online.

${ }^{1}$ According to Lewis-Beck and Stegmaier (2007), approximately 400 books and articles on economic voting have been published. The earlier studies focused on the relationship between US voting behavior and a number of measures that capture the macroeconomic situation (Gosnell and Coleman 1940; Kramer 1971; Fair 1978). Lewis-Beck (1988) provides similar findings using data from national elections in OECD countries. More recently, Brender and Drazen (2008) examine a large panel of countries and find a correlation between economic growth and incumbents' reelection in less developed countries and new democracies, but not in developed countries, with the exception of the United States.

${ }^{2}$ Wolfers (2007) finds that, in the United States, voters in oil-producing states tend to reelect incumbent governors during oil price rises and attributes it to voters' attribution errors. Brunner, Ross, and Washington (2011) exploit exogenous shifts to labor demand to identify the impact of economic conditions on policy preferences. They find that positive economic shocks reduce the support for redistributive policies.

${ }^{3}$ There is a body of research that exploits evidence from either natural disasters (Healy and Malhotra 2010) or terrorist attacks (Gardeazábal 2010; Montalvo 2011). 
eral convenient features. First, the Christmas Lottery is a syndicate lottery: around 75 percent of Spaniards participate in the lottery, and they typically share tickets with family, friends, and coworkers. In other words, the Spanish Christmas Lottery is more of a social event than a gamblers' lottery (Garvía 2007). Second, its economic impact is very large: Spaniards spend approximately $€ 3$ billion on the Christmas Lottery, amounting to about 0.3 percent of the Spanish GDP (in 2008, the average Spaniard spent $€ 70$ on the Christmas Lottery). Third, instead of awarding one big prize to a few individuals, as is the case in most lottery systems, the top prize, known as "the Fatty" ( $e l$ Gordo), is awarded to several thousand individuals sharing the same ticket number. Each winner receives around $€ 15,000$ per euro played, and the standard ticket costs $€ 20$. Winners of the second and third top prizes receive $€ 5,000$ and $€ 2,500$ per euro played, respectively. Because each number is mostly sold by one lottery outlet, winners tend to be geographically clustered. For each year of the period we consider, the province where the Fatty was sold receives an income shock equivalent, on average, to 3 percent of its GDP. The provinces where the second and third top prizes are sold receive an income shock equivalent to 1 percent and 0.5 percent of GDP, respectively. ${ }^{4}$ The remaining 47 provinces in Spain typically receive about one-third of the total amount they spent via minor prizes, approximately 0.1 percent of GDP.

Given these features, this paper uses provincial information on Christmas Lottery top prizes and expenditure, from 1986 through 2011, to identify random variations in annual provincial income. We find that the windfall brought by the Christmas Lottery has a significant effect on national electoral outcomes. In a province receiving Christmas Lottery awards equivalent to 1 percent of per capita GDP, the incumbent party enjoys a significant increase in the share of votes of approximately 0.21 percentage points. In terms of the number of awarded tickets, the incumbent obtains an additional 0.6 vote for every winning ticket sold in the province.

Because the incumbent cannot affect which province receives the Fatty, it would appear that voters should not be rewarding the incumbent. However, some individuals may fail to understand the random nature of a lottery (as in Guryan and Kearney [2008]). To investigate this issue further, we use information from surveys that were run every year shortly after Christmas. This evidence does not support the existence of an attribution error. Christmas Lottery prizes increase the (self-reported) propensity to vote for the incumbent, but they do not affect respondents' assessment of the government or the opposition.

There are at least two possible explanations that are consistent with the observed evidence. It might be due to psychological factors: perhaps when

${ }^{4}$ At the local level, the impact of lottery prizes tends to be much larger. For instance, in 2011 there was only one person in the winning town who did not possess a winning lottery ticket (New York Times, January 31, 2012). 
economic outcomes are good, voters become more lenient toward the incumbent; maybe because they feel happier. This hypothesis would be consistent with the evidence in the study by Healy, Malhotra, and Mo (2010), who, using information from a completely different setting, find that the outcome of US local college football games just before an election affects the incumbent's reelection. On the basis of this evidence, they argue that personal well-being might influence voting decisions on a subconscious level. Another possible explanation is that when voters become richer, they become more conservative and, in turn, their preference for the status quo is strengthened.

Our paper belongs to a growing literature that is turning to lottery data in order to examine the importance of exogenous (unearned) income shocks on a number of decisions. ${ }^{5}$ Our paper shares a caveat with other lottery studies in that our results may not be typical responses to other forms of unearned income. However, our paper differs from other lottery studies in at least two important respects. First, the Spanish Christmas Lottery is an unusual lottery system of syndicate play. In contrast to most lottery systems, which are gamblers' lotteries, a vast majority of Spaniards participate in the Christmas Lottery, making it more of a social event. Second, lottery studies typically analyze the effect of unexpected exogenous increases on individual income. Here we study the effect of an income shock that simultaneously affects several thousand households residing in the same geographic area. In that sense, the Spanish Christmas Lottery provides a unique setting to study how improvements in economic conditions affecting a whole community are connected with the reelection of incumbents.

The rest of the paper is organized as follows. In Section II, we describe the background information on Spanish elections and the Spanish Christmas Lottery. Section III provides a description of the data, and Section IV turns to the empirical analysis. Section $\mathrm{V}$ discusses the results and presents conclusions.

\section{Background}

Spain is a relatively young democracy. After Franco's death in 1975, a constitution was passed establishing Spain as a democratic constitutional mon-

${ }^{5}$ For instance, Imbens, Rubin, and Sacerdote (2001) study the effects of lottery prizes on labor supply, earnings, savings, and consumption. Other authors have analyzed the effect of lottery earnings on health and mortality (Lindahl 2005), on physical and mental health (Apouey and Clark 2015), on marriage and divorce (Hankins and Hoekstra 2011), and on individual bankruptcy (Hankins, Hoekstra, and Skiba 2011). Kuhn et al. (2011) analyze how lottery prizes affect winners' consumption, as well as their neighbors'. Doherty, Gerber, and Green (2006) survey lottery winners of varying amounts and observe that those who received higher lottery prizes show significantly lower support for redistribution policies. 
archy. Between 1986 and 2008, the period we consider in this paper, there have been seven elections and Spain has been ruled by the two main parties: the Partido Socialista Obrero Español (the main left-wing party; henceforth Socialist Party) for 14 years and the Partido Popular (the main rightwing party; henceforth People's Party) for 8 years.

The Spanish Christmas Lottery (Lotería de Navidad or Lotería del Gordo) is a national lottery game that is held every year on December 22 and is considered the biggest lottery event worldwide. It has been organized since 1812 by the National Lottery Organization, a branch of the Spanish Public Administration. The draw attracts wide television audiences, and when the top prize, the Fatty, is drawn, TV cameras travel to the winning location to show images of some of the happy winners. All in all, the process constitutes a popular Spanish Christmas tradition.

In his excellent account of syndicate lottery play, Garvía (2007) explains how syndicate play arose in Spain in 1862, when the Spanish lottery system was reformed. Because lotteries at the time were widely blamed for poverty and crime - as "many people, and particularly the uneducated, were unable to control their gambling instincts once they had fallen under their spell" (622) - the government decided to protect society by making lotteries unaffordable to the working poor. The rising cost of tickets did not, however, reduce the lottery's appeal among the working classes. On the contrary, revenues steadily increased as a result of the way in which players responded to the reform: since many of them could not afford to participate individually, they turned to their social networks and began syndicate playing.

Christmas Lottery tickets have five-digit numbers. Until 2004, there were 66,000 numbers played; between 2005 and 2010, there were 85,000 numbers played. Each number is split formally into several smaller units known as series (during our period of study, an average 150 series of each number were printed). Each series consists of 10 fractions (called décimos). In turn, each fraction can be further divided into smaller units or shares (called participaciones). People usually buy either a fraction, at a cost of $€ 20$ each, or a share at a cost of between $€ 2$ and $€ 5$. Depending on how many fractions and shares have been sold, for each number there might exist somewhere between 1,500 and 15,000 ticket holders.

Spain's National Lottery Organization manages the distribution of lottery tickets throughout lottery outlets across the country: 70 percent of revenues are distributed as prizes and the remaining 30 percent are retained for commissions paid to outlets, revenue for Internal Revenue, and administration costs. There are three main prizes, which account for approximately half of the total payout. For the top prize, the Fatty, all holders of fractions of the winning number win $€ 15,000$ for every euro played. The second and third prizes awarded winners $€ 5,000$ and $€ 2,500$ per euro played, 
respectively. ${ }^{6}$ In practice, a winning player with a fraction of the Fatty was awarded $€ 300,000$. According to the Spanish Survey of Household Finances (Bank of Spain), this amount represents approximately 10 times the average household income $(€ 32,000)$ and slightly more than the average level of assets held by the average Spanish household $(€ 257,000)$. There are also several thousand smaller prizes. During the period considered in this paper, Christmas Lottery prizes were announced on December 22 every year, but the winners of the main prizes were able to collect their prize only 10 days later, in January. All Christmas lottery prizes are tax exempt.

Each number is typically sold by one lottery outlet, for a number of reasons: ${ }^{7}$ first, given syndicate play, people belonging to the same network like to share the same number; second, it makes distribution easier; and third, it makes winners more visible. Which particular number is allocated to each outlet is determined randomly using a computer (National Lottery Organization 2009). Owing to the lottery design and given that most fractions in each number are sold by only one lottery outlet, the Fatty ends up awarding many relatively small prizes to several thousand individuals living in the same area. An exception is the lottery outlet of Sort, a small village in the province of Lleida, which receives buyers from all over the country for superstitious reasons (sort is the Catalan word for "luck"). In recent years Sort has sold ticket fractions with a total value over $€ 100$ million, about 3 percent of total sales. Another phenomenon that has increased over time is the availability of Christmas Lottery tickets for sale on the Internet. However, Internet sales of Christmas Lottery tickets remain relatively small: only around 2 percent of all tickets are purchased online. $^{8}$

Players' characteristics. - The Spanish Christmas Lottery is not the usual gamblers' lottery. According to survey information, 75 percent of the Spanish population aged 18 or more buy tickets. ${ }^{9}$ The expenditure on lottery by each player is fairly similar. For instance, the average individual in 2004 was planning to spend between $€ 40$ and $€ 60$, while relatively few people (less than 8 percent) were planning to spend over $€ 180$. Most Christmas Lottery players (62 percent) buy lottery tickets only in the particular case

${ }^{6}$ This information corresponds to years 2005-8. Between 1986 and 2004, the prizes per euro played were $€ 10,000, € 4,800$, and $€ 2,400$, respectively.

${ }^{7}$ According to our own calculations using data from the last 25 years, on average, 80 percent of fractions of the winning numbers were sold by one outlet each year.

${ }^{8}$ This information comes from a personal conversation with a representative of Ventura 24, one of Spain's top sellers of lottery tickets online.

9 Spain's Centre for Sociological Research has surveyed the Spanish population regarding their Christmas Lottery expenditure on six occasions over the period of study. These surveys where conducted in December 1988, January 1998, January 1999, January 2001, December 2004, and December 2009 (survey numbers 1,779, 2,274, 2,316, 2,406, 2,587, and 2,824 , respectively). They include information from 13,422 individuals. 
of the Christmas Lottery; only 10 percent of Christmas Lottery players are frequent lottery players.

The popularity of the Spanish Christmas Lottery may be due to its potential to induce regret among nonparticipants, as nonparticipants in a winning (personal or professional) network know that, had they purchased a ticket, they would also have won. Furthermore, individuals tend to share tickets. According to the survey data, 87 percent of the individuals who participate syndicate play. They share their tickets with relatives (64 percent), friends (33 percent), or coworkers (28 percent); 54 percent of players purchase shares (participaciones) at places they frequent. Lottery expenditure does not seem to be connected to political ideology. Socialist Party voters spend, on average, €62; People's Party voters spend slightly more: approximately $€ 68$.

\section{Data}

We draw information from four sources. First, we use information on Christmas Lottery top prizes and expenditure. Second, we use electoral outcome information. Third, we use survey data with information on the intention to vote and the subjective assessments of citizens on the economic and political situation. Fourth, we have collected information on the main macroeconomic variables available at the provincial level. In the Appendix we describe the sources of the data. Next we summarize the main variables.

\section{A. Christmas Lottery Data}

We use data on awards and on expenditure on the Christmas Lottery by province. In particular, we observe the province where tickets receiving the top three prizes were sold, as well as the total number of tickets sold in each province. Descriptive statistics for the lottery data are provided in panel A of table 1. The average yearly expenditure on the Christmas Lottery per province over the period is equal to 0.3 percent of GDP. This figure has remained stable over the last two decades. Christmas Lottery prizes amount to 70 percent of sales, approximately 0.2 percent of GDP. We observe the geographical distribution of the top three prizes, which make up around half of the total quantity assigned to prizes, that is, roughly 0.1 percent of GDP. We cannot observe the geographical distribution of the remaining 13,331 small prizes that are awarded in the Christmas Lottery, but given the random nature of the prizes, it can be safely assumed that their distribution is proportional to provincial expenditure on the Christmas Lottery. In what follows, by lottery prizes we mean the top three prizes.

Most tickets for the same number are usually sold within a single province. Owing to this geographical clustering, provinces where the winning 
TABLE 1

Descriptive Statistics: Information at the Provincial Level

\begin{tabular}{|c|c|c|c|c|c|}
\hline & $\begin{array}{l}\text { Mean } \\
(1)\end{array}$ & $\begin{array}{c}\text { Standard } \\
\text { Deviation } \\
\text { (2) }\end{array}$ & $\begin{array}{l}\text { Minimum } \\
(3)\end{array}$ & $\begin{array}{c}\text { Maximum } \\
\text { (4) }\end{array}$ & $\begin{array}{c}\text { Observations } \\
\text { (5) }\end{array}$ \\
\hline & \multicolumn{5}{|c|}{ A. Christmas Lottery: All Provinces } \\
\hline Expenditure (\% GDP) & .28 & .11 & .08 & .96 & 1,300 \\
\hline Top prizes ( $\%$ GDP) & .10 & .83 & 0 & 20.18 & 1,300 \\
\hline Expenditure per capita & 41 & 20 & 8 & 199 & 1,300 \\
\hline Top prizes per capita & 16 & 140 & 0 & 3,415 & 1,300 \\
\hline Number of winning fractions & 83 & 325 & 0 & 3910 & 1,300 \\
\hline \multirow[t]{2}{*}{ Winning fractions per capita $(\%)$} & .02 & .11 & 0 & 2.65 & 1,300 \\
\hline & \multicolumn{5}{|c|}{ B. Christmas Lottery: Winning Province } \\
\hline Expenditure (\% GDP) & .34 & .14 & .14 & .72 & 26 \\
\hline Top prizes $(\% \mathrm{GDP})$ & 3.46 & 4.76 & .41 & 20.18 & 26 \\
\hline Expenditure per capita & 55 & 31 & 22 & 129 & 26 \\
\hline Top prizes per capita & 557 & 822 & 80 & 3,415 & 26 \\
\hline Number of winning fractions & 1,337 & 869 & 80 & 3,910 & 26 \\
\hline \multirow[t]{2}{*}{ Winning fractions per capita $(\%)$} & .47 & .62 & .04 & 2.65 & 26 \\
\hline & \multicolumn{5}{|c|}{ C. Electoral Data } \\
\hline Electoral roll (in thousands) & 639 & 755 & 74 & 4459 & 350 \\
\hline Voter turnout $(\%)$ & 73.50 & 6.02 & 49.97 & 84.15 & 350 \\
\hline Incumbent votes $(\%)$ & 41.44 & 9.60 & 11.45 & 65.31 & 350 \\
\hline Socialist Party votes $(\%)$ & 39.69 & 8.36 & 18.40 & 62.22 & 350 \\
\hline \multirow[t]{2}{*}{ People's Party votes (\%) } & 38.10 & 12.81 & 7.00 & 65.31 & 350 \\
\hline & \multicolumn{5}{|c|}{ D. Macroeconomic Variables } \\
\hline Population (in thousands) & 831 & 998 & 91 & 6,490 & 1,300 \\
\hline GDP per capita & 14,281 & 3,647 & 6,113 & 27,238 & 1,300 \\
\hline Inflation rate & 3.92 & 1.92 & -1.59 & 10.95 & 1,300 \\
\hline Disposable income per capita & 10,397 & 1,930 & 6,105 & 16,985 & 800 \\
\hline Other transfers per capita & 818 & 192 & 505 & 4,023 & 800 \\
\hline Bank deposits per capita & 11,138 & 4,486 & 3,871 & 29,021 & 1,274 \\
\hline Bank loans per capita & 11,873 & 7,917 & 1,709 & 41,114 & 1,224 \\
\hline Vehicle sales & 539 & 203 & 181 & 2,188 & 1,200 \\
\hline Housing price per square meter & 842 & 412 & 328 & 2,555 & 1,050 \\
\hline Labor force participation (\%) & 52.28 & 5.41 & 38.05 & 67.25 & 1,300 \\
\hline Unemployment rate $(\%)$ & 15.86 & 7.50 & 2.96 & 43.57 & 1,300 \\
\hline
\end{tabular}

Note.-Panels A and D provide information on lottery and macroeconomic variables for the period 1986-2011 for the 50 Spanish provinces. Panel B provides lottery information for the province awarded with the top Christmas Lottery prize. Panel C includes electoral information at the provincial level for the national elections held in 1986, 1989, 1993, 1996, 2000, 2004, and 2008. All monetary variables are in constant year 2000 euros. Other transfers refers to the homonym chapter in the Income Accounts and includes residents' income from "scholarships, fines, lottery winnings, and games of chance." Other transfers and disposable income including information on other transfers are available only since 1995. Bank deposits (including overnight deposits, savings deposits, and deposits with agreed maturity) and loans are measured in September of every year. Owing to the nature of the bank deposits data, we exclude from this analysis the province of Madrid. Madrid hosts the central office of most banks, and for that reason, its aggregate information on deposits and loans includes information on accounting transactions that do not constitute true deposits or loans. Loan information is available since 1987. Information on vehicle registrations is available since 1988. Information on (estimated) housing prices is available for the period 1990-2010. Labor market information is measured during the last quarter of the year. 
tickets are sold tend to experience relatively large income shocks. Panel B in table 1 provides information on lottery prizes and expenditure for the province obtaining the Fatty each year (in terms of its GDP). In the winning province approximately 1,300 fractions are sold, one for every 200 potential voters. Because these fractions tend to be split in smaller shares (participaciones), this figure should be considered as a lower bound of the number of individuals receiving lottery winnings. The average income shock received by the province is equivalent to about 3.5 percent of provincial GDP and, in per capita terms, to about $€ 500$. The magnitude of the shock is comparable to typical variations in GDP growth at the provincial level over the period of study (the average GDP growth rate is 2.4 percent, with a standard deviation of 3.4 percent).

\section{B. Electoral Data}

In panel C of table 1, we display electoral information from national elections from 1986 through 2008. In the average province, the electoral roll is composed of around 600,000 people, with voter turnout at 74 percent. Incumbent parties received 41 percent of votes on average. Slightly more votes went to the Socialist Party (40 percent) than to the People's Party (38 percent), consistent with the Socialist Party winning five out of the seven national elections in our sample.

\section{Survey Data}

To complement the electoral data, we have also collected information from around 100 political surveys conducted during our period of study, covering information on approximately 300,000 individuals. These surveys are typically conducted in January, April, July, and October of each year.

Surveys typically ask respondents about the political party they would vote for were there a national election the following day and the political party they sympathize with. About 34 percent of respondents declare that they sympathize with the incumbent, and 28 percent would also vote for her (table 2). In most surveys, respondents are also asked to evaluate the incumbent party using a five-point scale (very good, good, average, poor, or very poor). In some surveys, the same five-point scale is used to inquire about respondents' evaluation of the opposition party and their assessment of the country's economic situation and/or the political situation. ${ }^{10}$ Respondents

\footnotetext{
${ }^{10}$ The questions can be respectively translated into English as follows: (1) If the national elections were to be held tomorrow, which party would you vote for? (2) In any case, which of the following parties do you sympathize with more, or which of the following parties do you consider closer to your own ideas? (3) Overall, how would you describe the management task led by the government party: very good, good, average, poor, very poor? (4) In general, how would you describe the political action taken by the opposition party: very good,
} 
TABLE 2

Descriptive Statistics: Survey Information

\begin{tabular}{lcccc}
\hline \hline & $\begin{array}{c}\text { Mean } \\
(1)\end{array}$ & $\begin{array}{c}\text { Minimum } \\
(2)\end{array}$ & $\begin{array}{c}\text { Maximum } \\
(3)\end{array}$ & $\begin{array}{c}\text { Observations } \\
(4)\end{array}$ \\
\hline $\begin{array}{l}\text { Individual characteristics: } \\
\text { Age }\end{array}$ & 46 & 18 & 98 & 290,374 \\
Female & .52 & 0 & 1 & 290,374 \\
Educational level: & .61 & 0 & 1 & 290,374 \\
$\quad$ Primary education or less & .24 & 0 & 1 & 290,374 \\
$\quad$ Secondary education & .14 & 0 & 1 & 290,374 \\
$\quad$ Higher education & & & & \\
Occupational status: & .45 & 0 & 1 & 290,374 \\
$\quad$ Employed & .10 & 0 & 1 & 290,374 \\
$\quad$ Unemployed & .20 & 0 & 1 & 290,374 \\
$\quad$ Retired & .06 & 0 & 1 & 290,374 \\
$\quad$ Student & .19 & 0 & 1 & 290,374 \\
$\quad$ Housekeeper & & & & 265,575 \\
Political views: & .34 & 0 & 1 & 282,799 \\
Sympathizes with the incumbent & .28 & 0 & 1 & 287,783 \\
Would vote for the incumbent & & & & 231,435 \\
Voted for the incumbent in & .32 & 0 & 1 & 177,619 \\
$\quad$ previous election & 3.0 & 1 & 5 & 214,789 \\
Assessment of the incumbent & 2.7 & 1 & 5 & 202,543 \\
Assessment of the opposition & 2.8 & 1 & 5 & 5 \\
Economic situation & 2.8 & 1 & 5 & \\
Political situation & & & & \\
\hline
\end{tabular}

Note.-The table reports information from 94 surveys conducted by the Spanish Center for Sociological Research between 1986 and 2009. Variables assessment of the incumbent, assessment of the opposition, economic situation, and political situation are codified in the following way: $5=$ very good, $4=\operatorname{good}, 3=$ average, $4=$ poor, and $5=$ very poor. Secondary education includes high school graduates and graduates from occupational training schools. Higher education includes individuals with at least 3 years of higher education.

also provided information about their voting behavior in the previous election. Unfortunately, there is no collection of respondents' subjective wellbeing.

\section{Macroeconomic Data}

We have gathered information on the main macroeconomic variables that are available at the provincial level, namely, GDP per capita, gross disposable household income (GDHI), population, inflation, bank deposits, bank loans, unemployment, labor force participation, and car sales. ${ }^{11}$ Offi-

good, average, poor, very poor? (5) Regarding Spain's overall economic situation, how would you describe it: very good, good, average, poor, very poor? (6) Regarding Spain's overall political situation, how would you describe it: very good, good, average, poor, very poor?

${ }^{11}$ Unfortunately, there is no direct information available on the value of car sales at the provincial level. We have collected information from tax records on the average price of cars sold in Spain in a given year, which we have multiplied by the total number of cars sold in the province to estimate the total expenditure on vehicles. 
cial data on housing prices based on market transactions are not available for our period of study; instead, we use the available estimates produced by the leading real estate valuation company in Spain. We summarize this information in panel D of table 1.

Note that while GDP and GDHI are typically highly correlated (there is a 95 percent correlation in our sample), the former does not include lottery prize income. ${ }^{12}$ Lottery prizes are included in the category of household income "other transfers." This category includes information on the disposable income of households that is derived from "scholarships, fines, lottery winnings, and games of chance." This information is available only since 1995.

\section{Empirical Analysis}

In this section, we investigate the relationship between economic outcomes and voting behavior in national elections in Spain. First we analyze the potential existence of economic voting in Spain. Next we exploit the random income shocks generated by the Christmas Lottery in order to deal with the potential endogeneity of variations in economic conditions.

\section{A. Economic Conditions and Electoral Outcomes}

Following the standard literature in the topic, in our first specification we regress the change in votes received by the incumbent on a number of measures of economic conditions: growth rate in income per capita, unemployment rate, consumer price index (CPI), and housing prices. That is, we run the regression

$$
\Delta \text { Votes }_{s, t}=\alpha_{t}+\beta \Delta \text { Economic variables }_{s, t}+\varepsilon_{s, t},
$$

where $\Delta$ Votes $_{s, t}$ denotes the variation in the percentage of votes received in province $s$ by the incumbent party in the national elections between the election in year $t$ and the previous election, and $\Delta$ Economic variables $_{s, t}$ denotes the variation in a certain macroeconomic variable over the electoral term in province $s .{ }^{13}$

\footnotetext{
12 The GDHI is derived from primary income by subtracting taxes on income and wealth as well as social contributions and similar transfers and adding all social benefits and monetary transfers (including lottery prizes).

${ }^{13}$ In Spain there are no term limits, and for national elections from 1986 through 2008, it is almost always the case that the incumbent party coincides with the incumbent politician. The only national election in which the incumbent party had a candidate that was not the incumbent politician was held in 2004.
} 
The inclusion of election fixed effects, $\alpha_{t}$, allows us to control for the effect of factors that may have simultaneously affected voting behavior in all provinces. The economic changes that we are thus identifying are variations relative to other provinces in the same term. In all of our regressions, we cluster standard errors at the province level.

In table 3 we report the ordinary least squares (OLS) results from estimating regression (1). We find a positive relationship between the growth rate of income per capita during the election cycle and the percentage of votes received by the incumbent. According to the estimates in column 1, an increase in 1 percent in the growth rate of per capita GDP of a province relative to the national average is associated with a significant increase in the incumbent's votes of 0.33 percentage points. This effect is smaller than the one estimated by Fair (2009) for US presidential elections: he finds a figure of 0.68 percentage points. We do not find a significant relationship between the incumbent's votes and other economic variables.

\section{B. Christmas Lottery}

In the previous subsection we have documented a positive relationship between economic conditions and the percentage of votes received by the incumbent. Nevertheless, it is not clear what this correlation reflects: it could be that good politicians both create policy conducive to economic growth and attract votes, but it could also be that, for some reason, economic growth leads voters to favor the incumbent. In order to deal with the endogeneity of economic conditions we exploit the evidence provided by the Spanish Christmas Lottery.

Given that we exploit information based on the location where lottery tickets are sold, first we examine whether it is safe to assume that individuals buy Christmas Lottery tickets in the same province where they live (and vote). Then, we document how the income shocks generated by the Spanish Christmas Lottery affect macroeconomic variables and voting behavior. Finally, we use survey information to investigate the mechanism behind the effect of the Christmas Lottery on the votes received by the incumbent.

\section{Do People Purchase Lottery Tickets in Their} Province of Residence?

We use information on the province where lottery tickets were sold. Some players, however, may exchange tickets with people in their networks who live in other areas, or they may purchase tickets while on vacation outside their area of residence. Since 1995, the National Accounts calculates household income at the provincial level including lottery winnings cashed 


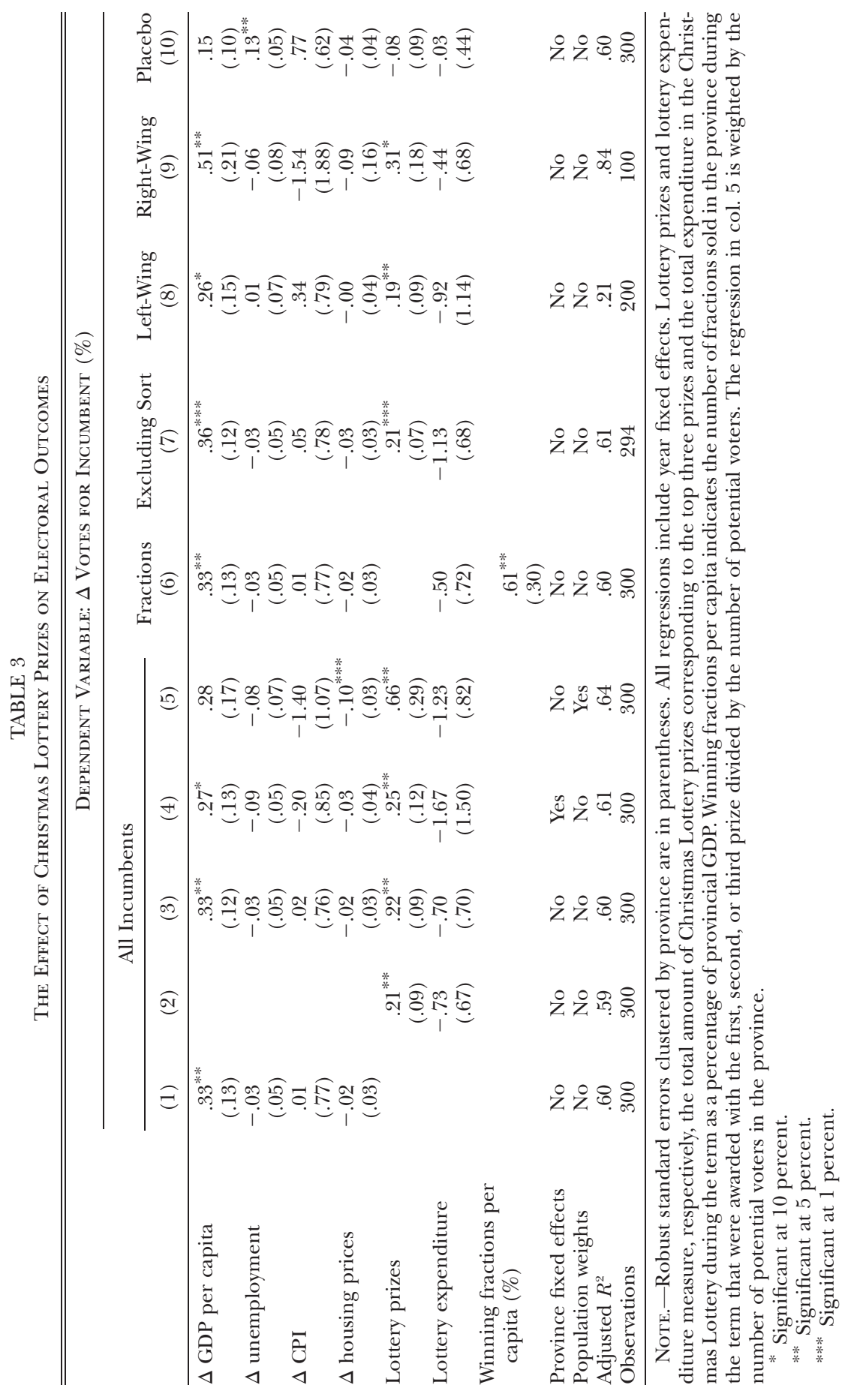

This content downloaded from 137.205.202.005 on January 21, 2020 03:37:34 AM All use subject to University of Chicago Press Terms and Conditions (http://www.journals.uchicago.edu/t-and-c). 
in the province. ${ }^{14}$ We use this information to verify that Christmas Lottery winners live in the same province where the lottery tickets were sold. In particular, we run the following regression:

$$
\Delta_{k} y_{s, t}=\alpha+\beta \text { Prizes }_{s, t}+\gamma \text { Expenditure }_{s, t}+\varepsilon_{s, t},
$$

where $\Delta_{k} y_{s, t}$ denotes the variation in the household income in province $s$

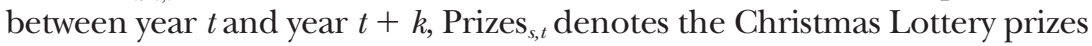
awarded to province $s$ over Christmas of year $t$ (and effectively collected in January of year $t+1$ ), and Expenditure en $_{s, t}$ refers to the value of Christmas Lottery tickets sold in province $s$. All variables are measured in per capita terms. We run this set of regressions for $k=1,2,3,4$. For example, for $k=1, \beta$ captures the impact of Christmas Lottery prizes awarded in the Christmas of year $t$ (and collected in January of year $t+1$ ) on the household income in the province in year $t+1$. All regressions include population weights, and standard errors are clustered by province. Additionally, as a placebo, we also consider the relationship between lottery prizes in a certain year and the variation in income the previous year $(k=-1)$.

The estimates from these regressions are displayed in figure 1. As expected, Christmas Lottery prizes are unrelated to variations in income over the previous year. National Accounts statistics also show that most prizes are collected in the province where the tickets were sold: each euro of lottery prizes implies an increase in households' disposable income in the province of 88 cents during the year in which prizes are collected. In later years, households' disposable income returns to levels comparable to those in nonwinning provinces.

We also distinguish between the household income from the lottery (National Accounts category "other transfers") and household income derived from other sources. Christmas Lottery prizes seem to have no effect on disposable income, other than their direct effect through prizes collected (upper row, fig. 1).

\section{The Macroeconomic Effects of the Christmas Lottery}

Before turning to voting data, we examine how the Christmas Lottery prizes are connected to a number of macroeconomic variables at the provincial level. This analysis is of interest in itself as it provides us with

\footnotetext{
14 The way prizes are accounted for in the National Accounts has changed over time. Until 2002, Christmas Lottery prizes were assigned to the year during which the prize was collected, typically the year following the draw. Since 2003, and following European regulations, all Christmas Lottery prizes are assigned to the year of the draw. In order to deal with this change in accounting, in our analysis the variables other transfers and GDHI are measured in the year of the draw until 2002 and in the following year from 2003 onward.
} 


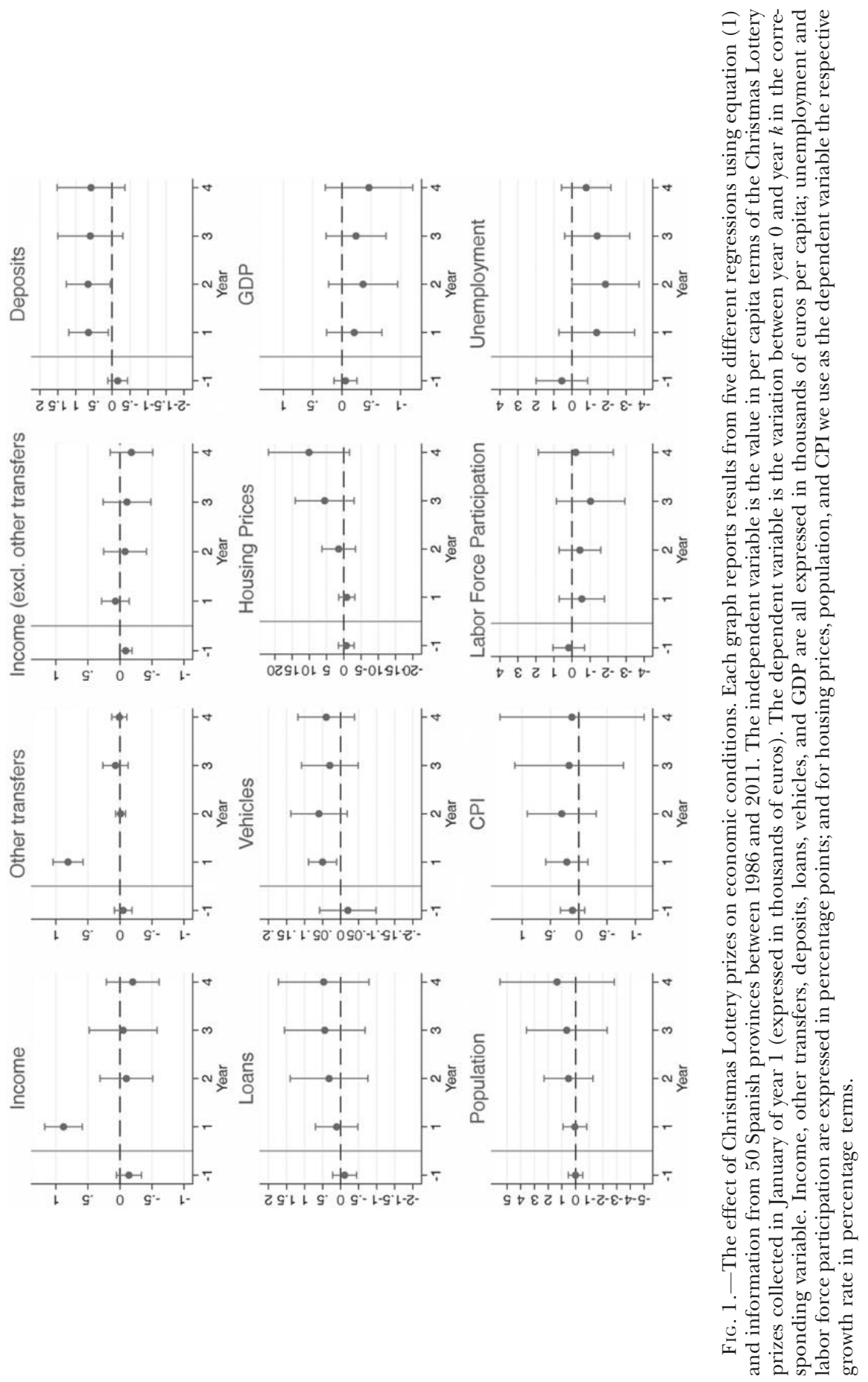

This content downloaded from 137.205.202.005 on January 21, 2020 03:37:34 AM All use subject to University of Chicago Press Terms and Conditions (http://www.journals.uchicago.edu/t-and-c). 
evidence on how individuals react to a temporary and unexpected unearned income shock. Additionally, it sheds light about the potential impact of the lottery on nonwinners, which helps to interpret the potential link between lottery prizes and voting behavior at the aggregate level.

We estimate the relationship between Christmas Lottery prizes and macroeconomic variables following the specification in equation (2). According to the standard life cycle/permanent income hypothesis, lottery winners are expected to smooth consumption by increasing their savings and their durable spending. This prediction is generally supported by the data. As reported in figure 1, we observe a significant increase in deposits roughly equivalent to 65 percent of lottery prizes shortly after lottery prizes are awarded. This effect seems to persist for at least 3 years following the lottery award. The impact on credit is theoretically ambiguous: some lottery winners might be paying off some of their debt, while some other winners might be using their new collateral to apply for new loans. In practice, these two effects seem to cancel each other: credit is not significantly affected by lottery prizes. We also examine whether Christmas Lottery awards affect vehicle sales. We find that in the year following a lottery prize, the winning province experiences a significant increase in vehicle registrations that is equivalent to 5 percent of the total Christmas Lottery winnings. Another possible way to smooth consumption is to invest in housing. Housing prices increase a few years after the prize has been awarded, but this effect is only marginally significant. The lack of significance may be related to the fact that the only available price measure is based on estimations performed by property valuation companies.

Next, we examine the impact of lottery prizes on the overall economic activity (GDP, population, and prices). This impact might depend on the extent to which lottery winners consume goods and services produced in their province of residence. According to trade data, the majority of the goods and services consumed in Spanish provinces tend to be imported from other provinces or countries. ${ }^{15}$ We do not observe any significant impact of lottery prizes on GDP in the years following a lottery shock. More precisely, with 95 percent confidence we can rule out increases in GDP of more than 30 percent of the amount of the lottery shock. There is no significant effect on either population growth or the CPI.

Finally, we examine the impact on the labor market. On the one hand, a positive income shock may decrease the labor supply of lottery winners. The magnitude of this effect would depend on the size of the prize. For instance, Imbens et al. (2001) find a significant decrease in the labor force participation of winners of at least $\$ 2$ million, but they do not find any

${ }_{15}$ The openness ratio of the average Spanish province between 1995 and 2007 was equal to 168 percent (C-Intereg database). We thank Carlos Llano for providing us with these data. 
significant effect on the labor force participation of winners of smaller sums (such as the amounts considered here). On the other hand, some nonwinners may decide to join the labor force. Results are generally not significant at standard levels. We observe a small, insignificant decrease in labor force participation. At the same time, there is a temporary marginally significant decrease in unemployment 1 year after the prize is awarded.

\section{Christmas Lottery and Electoral Outcomes}

We now regress the incumbent's votes on the Christmas Lottery prizes awarded in a given province during the term, controlling for lottery expenditure:

$$
\Delta \text { Votes }_{s, t}=\alpha_{t}+\beta \text { Prizes }_{s, t}+\gamma \text { Expenditure }_{s, t}+\varepsilon_{s, t},
$$

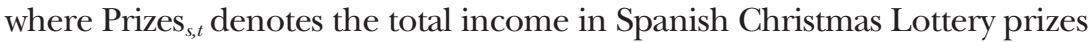
as a percentage of GDP received by province $s$ in the electoral term prior to year $t$, and Expenditure Est is the expenditure on the Christmas Lottery as a percentage of GDP during the same period.

We present OLS results from running regression (3) in column 2 of table $3 .{ }^{16}$ Incumbents receive significantly more votes in provinces awarded with Christmas Lottery prizes. Receiving 1 percent of GDP in the form of lottery winnings during the electoral term increases the votes received by the incumbent by approximately 0.21 percentage points, relative to the votes obtained by the incumbent in losing provinces. ${ }^{17}$ This result might reflect either an increase in votes for the incumbent in winning provinces or a reduction in votes for the incumbent in losing provinces. In winning provinces, the variation in votes could be due either to changes in the votes of winners or to spillovers to voters who did not win. That is, the results in this paper reflect the sum of the effect from lottery prizes on winners and the effect on the rest of the community. Interestingly, both GDP increases and Christmas Lottery winnings seem to have an effect of similar magnitude on the votes received by the incumbent.

In order to isolate the direct effect of lottery prizes on voting in column 3, we include economic variables together with lottery information.

${ }^{16}$ Results, available on request, are qualitatively similar if we use Christmas Lottery information in per capita terms instead.

${ }_{17}$ Above we have considered all the top prizes received by a province over the term prior to the election. If we distinguish between awards obtained the Christmas right before the election (on average, 4 months before the election is held) and awards obtained two and three Christmases before the election, the coefficients of the lagged variables are not statistically different; but the evidence is consistent with the effect of Christmas Lottery winnings fading out over time. If we distinguish between the top, second, and third Christmas Lottery prizes, only the Fatty leads to a significant increase in the share of votes received by the incumbent. However, the estimates are not precise. It is not possible to reject the hypothesis that the effect of the different top prizes is the same. Results are available on request. 
As a robustness check, in column 4 we run the same regression, now including as controls province fixed effects. In both cases, results remain unchanged. Thus far we have weighted equally the information provided by provinces that, in some cases, greatly differ in their size. In column 5 , we reestimate the specification in column 3, now weighting each observation by the potential number of voters in the province. The impact of lottery prizes in the weighted regression is three times larger $(0.66$ percentage points), but it is not significantly different from our previous estimates. ${ }^{18}$ In column 6 , instead of the amount of Christmas Lottery awards, we use the number of winning fractions sold (divided by the number of potential voters). We find that for every winning fraction sold, the incumbent receives 0.6 more of a vote. Because we do not have individual information on the voting behavior of the recipients of the Christmas Lottery prizes, we cannot separate to what extent, within provinces, individuals are voting on the basis of personal economic circumstances or on what they observe about their neighbors' economic circumstances. Given the magnitude of the effect, 0.6 vote per winning fraction, our results are consistent with two possibilities: either lottery prizes strongly affect only the voting behavior of winners or lottery prizes also affect the voting behavior of some individuals who were not awarded Christmas Lottery prizes.

In column 7 we exclude the province of Lleida from the sample. As explained before, this province includes the town of Sort (which means "luck" in Catalan), a town that attracts buyers from all around the country. Excluding this province improves the accuracy of the estimation, but the point estimate is basically unchanged. Next we would like to explore whether the effect is different according to the ideology of the incumbent. In particular, incumbent parties favoring less redistributive policies might benefit more from increases in income (Doherty et al. 2006; Brunner et al. 2011). In columns 8 and 9 we split the sample in two: elections in which the left-wing was the incumbent and elections in which the rightwing was the incumbent. Right-wing governments seem to benefit electorally more from economic growth. An increase in 1 percent of GDP is associated with an increase of votes for the incumbent of 0.51 percentage points when the People's Party is in power; the figure is 0.26 percentage points when the incumbent is the Socialist Party. Similarly, the estimated effect of lottery prizes is slightly larger for elections in which the rightwing was the incumbent, but the difference between the coefficients for the two parties is not statistically significant.

\footnotetext{
${ }^{18}$ We have also examined whether the effect of lottery prizes on the number of votes received by the incumbent varies depending on provincial GDP per capita, lottery expenditure, or population size. The accuracy of these estimations is relatively low, and we cannot reject the possibility that the effect is similar across different groups of provinces. Results are available on request.
} 
We have documented the existence of a positive (causal) relationship between lottery prizes and the share of votes received by the incumbent. As shown above, lottery awards do not affect population size. However, lottery prizes may have an effect on the number of people who turn out to vote. For instance, Brunner et al. (2011) find that positive economic shocks decrease voter turnout. There is also some additional evidence that subjective well-being might affect turnout (Dolan, Metcalfe, and Powdthavee 2008). In table 4 we investigate this possibility by regressing electoral participation on Christmas Lottery prizes and controls. The main determinant of participation is the unemployment rate. An increase in the unemployment rate of 1 point is associated with an increase in participation of 0.20 percentage points (col. 1 ). The estimated coefficient of lottery prizes is negative, but it is not statistically significant at standard levels, and the magnitude is small compared to the effect of lottery awards on the votes received by the incumbent.

Finally, we check for the robustness of our results using placebo Christmas Lottery prizes. We regress the votes received by the incumbent on the Christmas Lottery prizes after an election. If the results in this paper are due to lottery winnings affecting voting behavior, there should be no relationship between the two. Results shown in column 10 of table 3 confirm that the Christmas Lottery awards received after the election are not correlated with the votes received by the incumbent.

\section{Christmas Lottery and Voting: Evidence from Survey Information}

The incumbent tends to receive more votes in provinces awarded with the Fatty. However, we do not know which individuals are affected or the underlying mechanism. We examine an independent database, a largescale survey, in order to investigate these issues. Specifically, we want to investigate if voters in awarded provinces tend to reelect the incumbent because (in what would be an example of attribution error) they believe, somehow, that the quality of the incumbent has improved. In order to minimize the potential effect of economic spillovers induced by lottery prizes, we focus our attention on surveys conducted in January, just a few weeks after the Christmas Lottery. The general specification that we use is as follows:

$$
\begin{aligned}
z_{i, s, t}= & X_{i, t} \alpha+\beta \text { Prizes }_{s, t-1}+\gamma \text { Expenditure }_{s, t-1} \\
& +\sum_{t} \delta_{t} S_{t}+\sum_{s, t} \lambda_{s, t} D_{s, t}+\varepsilon_{i, s, t}
\end{aligned}
$$

where $z_{i, s, t}$ denotes the survey responses of individual $i$ in province $s$ at time $t$;

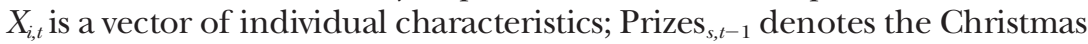




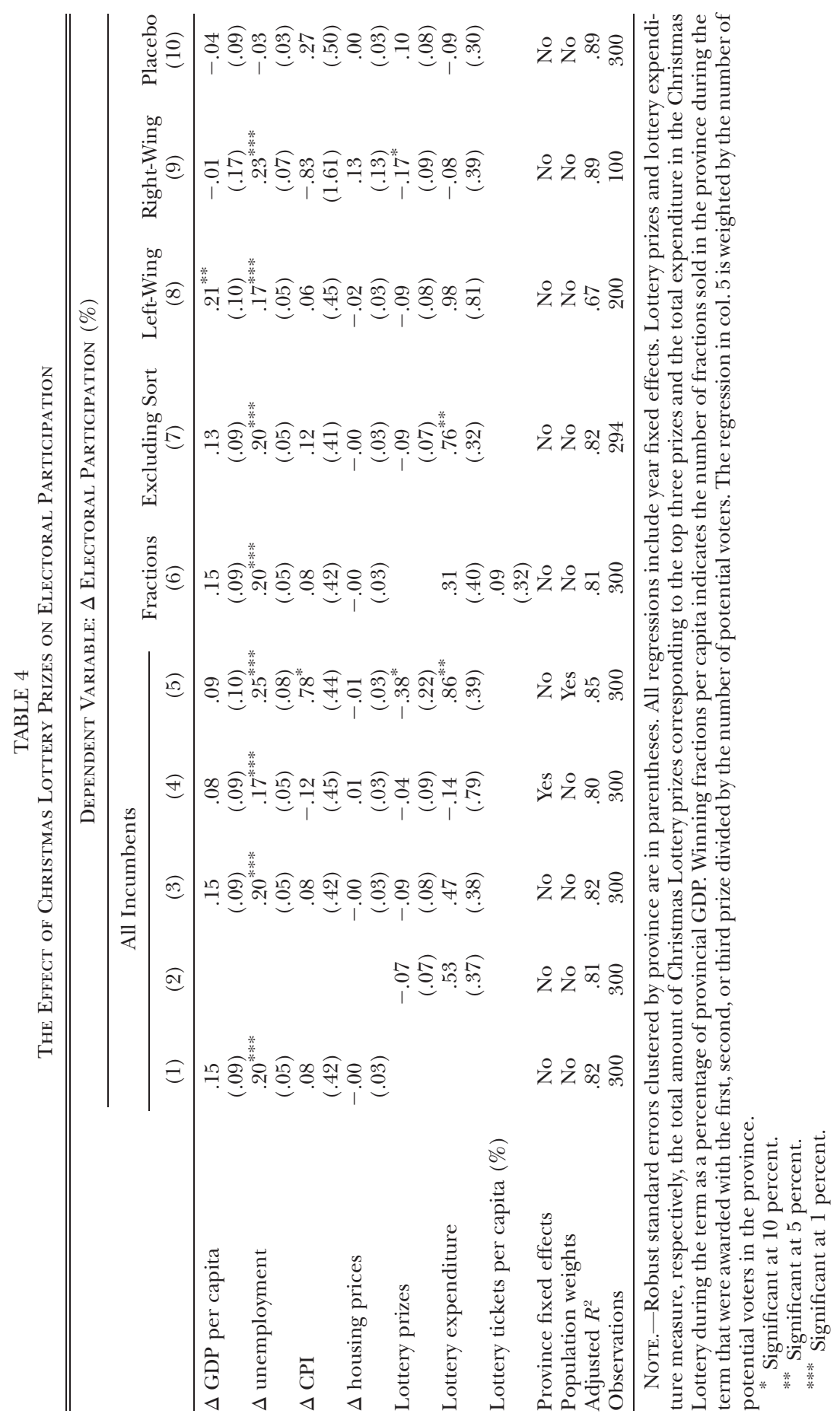

This content downloaded from 137.205.202.005 on January 21, 2020 03:37:34 AM All use subject to University of Chicago Press Terms and Conditions (http://www.journals.uchicago.edu/t-and-c). 
Lottery income awarded in the province the month prior to the survey as a percentage of GDP; Expenditure $e_{s, t-1}$ is the corresponding expenditure on the Christmas Lottery; $S_{t}$ is a set of survey dummies; and $D_{s, t}$ is a set of dummies for period and province, where each period includes three surveys before Christmas (April, July, and October) and a survey after Christmas (January). In other words, we are comparing survey responses in the same province before and shortly after Christmas.

First, we look at the respondent's intention to reelect the incumbent. As can be seen in column 1 of table 5 , in provinces recently awarded with Christmas Lottery prizes, individuals are more likely to state that they intend to vote for the incumbent. ${ }^{19}$ This effect is significant at the 5 percent level. The sign of this coefficient is consistent with the results obtained with the aggregate electoral data (table 3), but its magnitude is larger (1.2 vs. 0.66 , if we consider the effect estimated in the weighted regression in col. 5 of table 3). This difference may reflect the fact that here we are capturing the effect of lottery prizes shortly after Christmas. In columns 2-4 we distinguish between respondents according to previous electoral behavior. The evidence is consistent with lottery prizes having an effect on voters who did not support the incumbent in the previous election, but only marginally so. In column 5, we use as the dependent variable an indicator that takes the value one if respondents declare that they sympathize with the incumbent. The magnitude of the effect is similar but the sample size is slightly smaller, and in this case the coefficient is not statistically significant.

In column 6, we use the respondents' assessment of the incumbent as the dependent variable. The effect goes in the same direction, but in neither case do we observe any significant association with the Christmas Lottery prizes. In other words, we fail to find that respondents in provinces awarded with more Christmas Lottery prizes perceive the incumbent as of better quality. In column 7 we look at the respondents' assessment of the opposition party: we do not find any significant relationship with the Christmas Lottery prizes. In columns 8 and 9 we show results from using the respondents' assessment of the economic and the political situation at the national level as dependent variables, respectively. There is no relationship between either of these and the Christmas Lottery prizes. That is, voters in winning provinces do not seem to overestimate the economic situation at the national level: it does not seem that the greater propensity to reelect the incumbent is due to voters' wrongly thinking that the national economic situation has improved. Overall, the evidence does not point toward the hypothesis of attribution errors.

\footnotetext{
${ }^{19}$ Considering prizes awarded 4-7 months prior to the survey yields qualitatively similar results.
} 


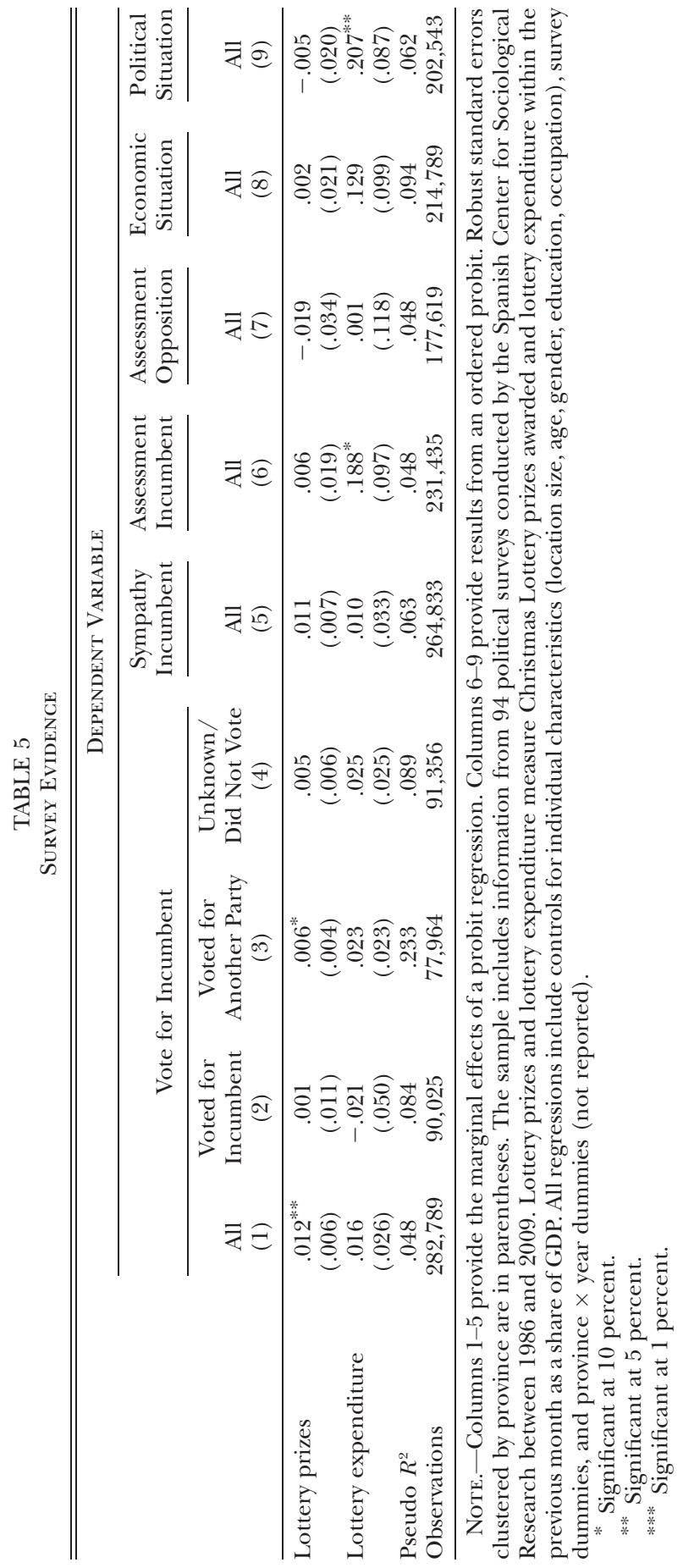

This content downloaded from 137.205.202.005 on January 21, 2020 03:37:34 AM All use subject to University of Chicago Press Terms and Conditions (http://www.journals.uchicago.edu/t-and-c). 


\section{Conclusions}

There is a large body of evidence suggesting that good economic outcomes are associated with the reelection of incumbent politicians. Owing to the endogeneity of good economic outcomes, the nature of this relationship is not clear. In order to deal with this problem we exploit the exceptional evidence provided by the Spanish Christmas Lottery. This lottery, held every year around Christmas, offers several convenient features. First, its economic impact is very large. Spaniards spend about 0.3 percent of the Spanish GDP on the Christmas Lottery. Second, the Christmas Lottery is a syndicate lottery: over 75 percent of Spaniards participate, and they typically share tickets with family, friends, and coworkers. Third, there are many shares for the same number, meaning that the Fatty awards many relatively small prizes to several thousand individuals. Because each winning number is typically sold by one lottery outlet, winners tend to be geographically clustered.

Given these features, we are able to use provincial information on the Christmas Lottery prizes and expenditure to identify random increases in provincial income. In the main winning province, approximately 1,300 lottery fractions are awarded. The number of households receiving lottery earnings is probably larger, given that each fraction is often divided into smaller shares. We find that, despite the fact that it is understood that the lottery outcome is completely random, the incumbent party tends to obtain relatively more votes in these provinces. Each lottery fraction awarded is associated with, roughly, an additional one-half of a vote for the incumbent (table 3, col. 6). On aggregate, in the average winning province the mean income shock is equivalent to 3 percent of provincial GDP, and the incumbent party enjoys a significant increase in the share of votes: approximately 0.63 percentage points (table 3 , col. 2 ). This effect is robust to a number of robustness checks, including the use of provincial population weights, provincial fixed effects, placebo lottery prizes, as well as the exclusion of outliers. Right-wing incumbents seem to benefit more from lottery prizes, but the difference is not statistically significant. We do not find evidence supporting the hypothesis that these differences in voting behavior can be explained by variations in voter turnout.

What is the source of the observed effect? The literature has mainly relied on two potential explanations for the positive correlation between economic conditions and incumbents' electoral performance: asymmetric information (voters learn about politician quality and effort through economic conditions) or attribution errors (voters are mistaken regarding the cause of good economic outcomes). Our results are not consistent with either of these hypotheses; if anything, they seem to be at odds with both, given that voters are expected to be well aware of the randomness of the Christmas Lottery winnings. Information from surveys span- 
ning our period of study allows us to further investigate the mechanism underlying this effect. The evidence from survey data confirms that respondents in winning provinces are more likely to vote for the incumbent, but they do not think that the incumbent is more competent or that the national economic or political situation has improved. The relatively short time elapsed between the Christmas lottery and the survey helps to minimize the possibility that economic spillovers have affected nonwinners living in the area.

The results in this paper suggest that the positive correlation between good economic outcomes and incumbent reelection may reflect something other than voters being uninformed. Increases in wealth may reinforce voters' preference for the status quo, or in the same vein, perhaps when voters are happier, they become more lenient with the incumbent.

\section{Appendix}

TABLE A1

DATA SOURCES

\begin{tabular}{ll}
\hline \hline Variable & \multicolumn{1}{c}{ Source } \\
\hline Lottery data & Sistemas Técnicos de Loterías del Estado \\
Electoral data & Ministry for Home Affairs \\
Survey data & Centre for Sociological Research \\
Population & National Statistics Institute \\
GDP & Fundación BBVA and IVIE \\
CPI & National Statistics Institute \\
Gross disposable household & National Statistics Institute \\
$\quad$ income (GDHI) & National Statistics Institute \\
Other transfers & Statistics Bulletin, Bank of Spain \\
Bank deposits and loans & Dirección General de Tráfico, Ministry for \\
Vehicle registrations & Home Affairs \\
& Tax agency and National Statistics Institute \\
Vehicle prices & Sociedad de Tasación (1986-2008) and BBVA \\
Housing prices & (1990-2010) \\
Labor market & Labor Force Survey, National Statistics Institute \\
\hline
\end{tabular}

\section{References}

Apouey, Benedicte, and Andrew E. Clark. 2015. "Winning Big but Feeling No Better? The Effect of Lottery Prizes on Physical and Mental Health." Health Econ. 24 (5): 516-38.

Asworth, Scott, and Ethan Bueno de Mesquita. 2014. "Learning about Voter Rationality." Manuscript, Harris School Public Policy, Univ. Chicago.

Brender, Adi, and Allan Drazen. 2008. "How Do Budget Deficits and Economic Growth Affect Reelection Prospects? Evidence from a Large Panel of Countries." A.E.R. 98 (5): 2203-20.

Brunner, Eric J., Stephen L. Ross, and Ebonya L. Washington. 2011. "Economics and Policy Preferences: Causal Evidence of the Impact of Economic Conditions 
on Support for Redistribution and Other Proposals." Rev. Econ. and Statis. 93 (3): 888-906.

Doherty, Daniel, Alan S. Gerber, and Donald P. Green. 2006. "Personal Income and Attitudes toward Redistribution: A Study of Lottery Winners." Polit. Psvchology 27 (3): 441-58.

Dolan, Paul, Robert Metcalfe, and Nattavudh Powdthavee. 2008. "Electing Happiness: Does Happiness Affect Voting and Do Elections Affect Happiness?" Discussion Papers in Economics, no. 30, Univ. York.

Fair, Ray C. 1978. "The Effect of Economic Events on Votes for President.” Rev. Econ. and Statis. 60 (2): 159-73.

. 2009. "Presidential and Congressional Vote-Share Equations." American I. Polit. Sci. 53 (1): 55-72.

Gardeazábal, Javier. 2010. "Vote Shares in Spanish General Elections as a Fractional Response to the Economy and Conflict." Economics of Security Working Paper no. 33, German Inst. Econ. Res., DIW Berlin.

Garvía, Roberto. 2007. "Syndication, Institutionalization, and Lottery Play." American I. Sociology 113 (3): 603-52.

Gosnell, Harold F., and William G. Coleman. 1940. "Political Trends in Industrial America: Pennsylvania as an Example.” Public Opinion O. 4 (3): 473-84.

Guryan, Jonathan, and Melissa S. Kearney. 2008. "Gambling at Lucky Stores: Empirical Evidence from State Lottery Sales.” A.E.R. 98 (1): 458-73.

Hankins, Scott, and Mark Hoekstra. 2011. "Lucky in Life, Unlucky in Love? The Effect of Random Income Shocks on Marriage and Divorce." J. Human Resources 46 (2): 403-26.

Hankins, Scott, Mark Hoekstra, and Paige Marta Skiba. 2011. "The Ticket to Easy Street? The Financial Consequences of Winning the Lottery." Rev. Econ. and Statis. 93 (3): 961-69.

Healy, Andrew, and Neil Malhotra. 2010. "Random Events, Economic Losses, and Retrospective Voting: Implications for Democratic Competence.” O. I. Polit. Sci. 5 (2): 193-208.

Healy, Andrew, Neil Malhotra, and Cecilia Hyunjung Mo. 2010. "Irrelevant Events Affect Voters' Evaluations of Government Performance." Proc. Nat. Acad. Sci. United States of America 109 (29): 12804-9.

Imbens, Guido, Don Rubin, and Bruce Sacerdote. 2001. "Estimating the Effect of Unearned Income on Labor Supply, Earnings, Savings, and Consumption: Evidence from a Sample of Lottery Players." A.E.R. 91 (4): 778-94.

Kramer, Gerald H. 1971. "Short-Term Fluctuations in U.S. Voting Behavior, 18961964." American Polit. Sci. Rev. 65 (1): 131-43.

Kuhn, Peter, Peter Kooreman, Adriaan R. Soetevent, and Arie Kapteyn. 2011. "The Effects of Lottery Prizes on Winners and Their Neighbors: Evidence from the Dutch Postcode Lottery." A.E.R. 101 (5): 2226-47.

Lewis-Beck, Michael S. 1988. Economics and Elections: The Major Western Democracies. Ann Arbor: Univ. Michigan Press.

Lewis-Beck, Michael S., and Mary Stegmaier. 2007. "Economic Models of Voting." In The Oxford Handbook of Political Behavior, edited by Russell Dalton and HansDieter Klingemann, 518-37. Oxford: Oxford Univ. Press.

Lindahl, Mikael. 2005. "Estimating the Effect of Income on Health and Mortality Using Lottery Prizes as an Exogenous Source of Variation in Income." J. Human Resources 60 (1): 145-68.

Montalvo, Jose G. 2011. "Voting after the Bombing: A Natural Experiment on the Effect of Terrorist Attacks on Democratic Elections." Rev. Econ. and Statis. 93 (4): 1146-54. 
National Lottery Organization. 2009. Dossier de prensa, Sorteo de Navidad. Madrid: Nat. Lottery Org.

Nordhaus, William D. 1989. "Alternative Approaches to the Political Business Cycle." Brookinos Pabers Econ. Activity (2): 1-68.

Ross, Lee D., and Richard E. Nisbett. 1991. The Person and the Situation. New York: McGraw-Hill.

Wolfers, Justin. 2007. "Are Voters Rational? Evidence from Gubernatorial Elections." Manuscript, Wharton School, Univ. Pennsylvania. 